\title{
Implementation of Forecasting in Measuring the Quality Level of Community Services in PLN Kota Lhokseumawe
}

\author{
Yuli Asbar $^{1}$, Badriana $^{2}$, Razif $^{3}$, Sapna Biby ${ }^{1}$, Mutammimul Ula $^{4}$ and Widyana Verawaty Siregar ${ }^{1}$ \\ \{ Joely_asbar@yahoo.com, badriana@unimal.ac.id, razifishak@gmail.com, bby_sapna@yahoo.co.id, \\ mutammimul@unimal.ac.id, widyana.verawaty@unimal.ac.id $\}$ \\ ${ }^{1}$ Jurusan Manajemen, Fakultas Ekonomi dan Bisnis, Universitas Malikussaleh, Lhokseumawe, \\ Indonesia, \\ ${ }^{2}$ Jurusan Teknik Elektro, Fakultas Teknik, Universitas Malikussaleh, Lhokseumawe, Indonesia \\ ${ }^{3}$ Jurusan Akutansi, Fakultas Ekonomi dan Bisnis, Universitas Malikussaleh, Lhokseumawe, Indonesia, \\ ${ }^{4}$ Sistem Informasi, Fakultas Teknik, Universitas Malikussaleh, Lhokseumawe, Indonesia
}

\begin{abstract}
The level of forecasting measurement is very important in seeing the forecasting level of public service satisfaction, the concept of forecasting can capture the pattern of service data provided by PLN Kota Lhokseumawe to the community. Then the impact on public services that will come. so that PLN can provide the best service for the community. The pattern of least squares models capture the pattern of past data is then used to project the data come. Quality variables of services such as responsiveness include patience and attention to customers, speed of response regarding customer complaints, resolution of complaints faced by customers can be resolved. The results of the questionnaire on each of its variables of each month will be entered into the model Least Square. The value of questionnaires from 100 customers taken on average includes Reliability, 66.8 Emphaty, 57.2, Responsiveness, 65.5, Tangible, 65.5, Assurance 63.5 and a questionnaire for service satisfaction 58.8. Distribution of the questionnaire from the various areas of the city Lhokseumawe. Tests taken from the value of each month covering the month of January the data Actual $(\mathrm{Y})=66$, Actual Data February 57, Actual Data March 65, Actual Data April 65 May 63 Data Actual, Actual Data June 58, Total Data Actual is 374 . Value a 62.33 and b value is -0.3142 for forecasting in the following month $\mathrm{Y} 1=63.90, \mathrm{Y} 2=63.276$ and $\mathrm{Y} 3=62.647$. The results of this study are expected to make a reference to the PLN in making decisions on issues of public services. Then this study can measure the level of satisfaction with quality of services konsumsen granted PLN from each region.
\end{abstract}

Keywords: Quality of Service, Community Satisfaction, forecasting, least square

\section{Introduction}

Improving service satisfaction to the community is a positive impact to support creativity and trust given by customers PT. PLN Kota Lhokseumawe. but in practice PT PLN Lhokseumawe likely to have complaints against the services provided by these companies. The number of complaints such as a schedule of power outages that have no certainty of life time, employees who serve do not act quickly in paying attention to consumer complaints, cable disruption from house to house, too late in normalizing the electric current. so that these conditions inhibit the activity of customers in the event of a power outage problems.

Supposedly services provided to consumers must be optimized in accordance with the best pelayanana for each customer. Therefore, a model is needed to be able to predict in 
measuring the level of quality of public service in the city of lhokseumawe PLN. Service needs to be given to the consumer must be optimized in accordance with the needs of society and the major industries located in the region. Then the importance of completing the services rendered were the main focus in the community along with the increasing socio-economic growth of the community it self.

Therefore, strategies and models for forecasting are needed in the adjustment between the fulfillment of community satisfaction services. The forecasting model must be able to predict the pattern of the old service data which is then used to project future service data in accordance with the quality variable of the service. Such responsiveness includes patience and attention to customers, speed of response regarding customer complaints, resolution of complaints faced by customers can be resolved.

So as to provide the best service for the community. Then variable Reliability, Empathy, Tangible, Assurance, service satisfaction questionnaires, each of which has a sub-model questions that will be filled by the customer. The models in this study using least square forecasting models. Service measurement is a measurement of the number of grievances that have occurred within a few months and then analyze the current situation and earlier as a source of information to predict the state of the service in the future.

Further research is expected to result in the value of satisfaction of each customer with the least squares forecasting model right so that it can be used as a reference for the PLN in making decisions on issues of service to the community. Then this study can measure the level of consumer satisfaction on the quality of services provided by PLN. Then can measure the level of satisfaction with quality of services konsumsen have been given and to measure customer satisfaction levels of each area in the city of Lhokseumawe.

\section{Literature Review}

\subsection{Forecasting}

According to (Prasetya and Lukiastuti, 2009) Forecasting is an attempt to predict the future state through keadan testing in the past. The essence forecasting is forecast events in the future on the basis of patterns in the past, and the use of policy towards the projections with patterns in the past. The concept of forecasting is the initial part of a decision making process. Before forecasting it must be known in advance what the problem is in the decision making (Ginting, 2007). (Pardede, 2005) Forecasting is an objective calculation and using past data, to determine something in the future.

(Heizer and Render, 2015), Forecasting demand is forecasted demand for the products or services of the company. Projected demand for products or services of a company, this forecast can also be called sales forecasting which controls production, capacity and scheduling systems and becomes input for financial planning, marketing, and human resources. The decisions taken will affect a manager's success or failure of a company in the future. by knowing how many requests the next period and how much production must be done by the company, a manager must be able to predict the demand for products produced for the next period (Heizer and Render, 2015). (Heizer and Render, 2009) on the type of forecasting can be divided into several types. Judging from future operations planning, forecasting is divided into 3 types, namely:

- Forecasting economic (economic forecast) explains the business cycle by predicting inflation, the availability of money and other planning indicators. 
- Technological forecast (technological forecast) takes into account the level of technological progress that can launch exciting new products, which require new plants and equipment.

- Forecasting demand (demand forecast) are projected demand for the products or services of the company.

Statistics provides data analysis tools for various fields of science. Its uses vary: studying diversity due to measurement, controlling processes, formulating information from data, and helping decision-making based on data. Statistics, because of their objective nature, is often the only reliable tool for needs.

\subsection{Service Quality}

Quality should start from the needs of customers and end on customer perception ((Kotler and Kevin, 2009); in Sulistyo, 1999). This means that a good quality image unfounded perceptions of service providers, but based on customer perception. Customer perception of service quality is a thorough assessment of the benefits of a service. Service quality is described as a statement about attitude, a relationship that results from a comparison between expectations and performance.

Customer expectations are the customer's confidence before trying or buying a product, which is used as a standard in assessing the performance of the product. Customer expectations are shaped and based on several factors, including past shopping experiences, friends 'or relatives' opinions, company information and promises (Armstrong and Kotler, 1999).

While the concept of quality, according to the American Association for Quality Control is the overall characteristics and characteristics of a product / service in terms of its ability to meet the needs that have been determined or are latent. The concept of quality itself is basically relative, which depends on the perspective used to determine the characteristics and specifications. Basically there are three quality orientation should be consistent with each other: (1) the perception of the consumer, (2) the product / service, and (3) process. Factors that influence consumer satisfaction, companies need to take measurements of customer satisfaction in marketing activities. The measurement of customer satisfaction aims to make the company evaluate the extent to which the company's performance in satisfying consumers. Customer satisfaction measurement can be done in various ways as disclosed (Kotler, 2010) Kotler (2000) are as follows: 1. System Complaints and suggestions; 2. The customer satisfaction survey system; 3. Ghost Shopping; 4. Analysis of Consumer Loss. Service quality according to (Stemvelt, 2004) is a perception of the overall quality revolution which is thought and becomes an idea that must be formulated (formulation) so that its implementation (implementation) can be re-tested (evaluation). to be a dynamic process, ongoing, continuous in meeting customer satisfaction. service quality application forms by applying the concept of "RATER" proposed by (Parasuraman, 2001) revealed that there are five main indicators that affect the quality of service, namely in the form of tangibles, reliability, responsiveness, assurance. ), and empathy (empathy).

\subsection{Method Least Square}

Forecasting is an activity or efforts to find out (event) will happen in the future regarding the specific object by using the experience or historical data, to meremalkan pengjuian circumstances in the future through the past (Subagyo, 1999). Time series data is data which is 
a set of time series data at a specific time period. Forecasting time series forecasting based on the past behavior of the data to be projected into the future by using mathematical equations and statistics. (Prasetya and Lukiastuti, 2009) The Least Square method is the most widely used method for determining data trend equations. The least squares method is divided into two cases, namely even data cases and odd data cases. The Least Square method (least squares) is most often used to predict Y. (Ginting, 2007) the least square method uses certain statistical and mathematical calculations methods to determine straight line functions instead of broken lines formed by historical company data.

The least squares method, which is better known as the Least - Squares Method, is one method of 'approach' the most important in the world of engineering to: (a) regression or the establishment of equality of points - of data points diskretnya (modeling), and (b ) measurement analysis (in model validation). In general, the linear equation of the least squares method (Supranoto, 2000) are as follows:

Y_n : Forecasting future (Forecasting)

A : a constant number

B : slope or trend line biased coefficient

$\mathrm{x}$ : time period or year difference $(\mathrm{x}=0,1,2,3, \ldots, \mathrm{n})$

As for calculating the value of $a$ and $b$ is used the following formula:

$\mathbf{Y}_{\mathbf{n}}=\mathbf{a}+(\mathbf{b} \cdot \mathbf{X})$

Ket:

$\mathrm{Y}_{\mathrm{n}}$ : Forecasting future (Forecasting)

a : constant number

$\mathrm{b}$ : slope atau koefisien kecondongan garis trend

$\mathrm{X}$ : time period or year difference $(\mathrm{x}=0,1,2,3, \ldots, \mathrm{n})$

As for calculating the value of $\mathrm{a}$ and $\mathrm{b}$ is used the following formula:

$\mathbf{b}=\frac{\sum \mathbf{X Y}}{\sum \mathbf{X}^{2}}$

$\mathbf{a}=\frac{\sum \mathbf{Y}}{\mathbf{n}}$

Ket :

$\sum \mathrm{XY}$ :Cumulative amount of time multiplied by historical data

$\sum X^{2}$ :the average number of time periods squared

$\sum \mathrm{Y}$ :Average amount of water distribution

$\mathrm{n} \quad$ :number of time periods ( years)

\section{Methodology} follows:

Research Stages in composing this object the researchers used the Stages of Research as

\subsection{Data retrieval}

At this stage the researchers selected data on the number of service quality in communities restricted to the data services provided at the time of distribution of the questionnaire. 


\subsection{Observation Method}

Observation method is direct observation on the problem object in the field, the researcher observes and records directly about the services that have been given and looks at the level of community satisfaction to support forecasting data in the problem under study.

\subsection{Interview Method}

Distributing questionnaires to the public regarding customer satisfaction with service. This sees the performance of service quality to customers of PT PLN Kota Lhokseumawe.

\subsection{Application design phase}

At this stage researchers design and design database applications in the form of relationship data that can produce accurate data using the least square method.

\subsection{Report}

At this stage the researcher designs a report consisting of forecasting reports on the number of service satisfaction to the community in the form of reports and graphs.

\subsection{Implementation}

Data processing rate of the number of services to the community satisfaction then the researchers combined the least squares method with the application system, which is linked to adopt the previous year.

\section{Results And Discussion}

The object used as the research is the type of service provided by PT PLN Persero Lhokseumawe City which is viewed per service for each forecast, the number of forecasts for the next few years. Forecasting method of least squares In Kota Lhokseumawe is a system that processes the data and make the process of forecasting by the forecasting system for a year and a forecast for the following year.

With this system the findings of which are targeted is the least squares method to look at the quality of service within a few years of each area of the city Lhokseumawe consisting of each variable that can measure the level of people's satisfaction with quality of services provided by the PLN using forecasting models. Finally, it can be a reference in policy making in terms of providing quality services to the community.

The questioner variable in the forecasting model of information system in the measurement of people's satisfaction levels on service quality PT PLN city of Lhokseumawe is as follows:

Table 1. Quality Questionnaire for Reliability Services

\begin{tabular}{ccccc}
\hline Questionnaire & S & \multirow{2}{*}{ B } & T & ST \\
Service Quality & B & & B & B \\
\hline Reliability & 5 & 4 & 3 & 2 \\
\hline $\begin{array}{l}\text { Information } \\
\text { about the } \\
\text { electricity } \\
\text { outage }\end{array}$ & & & & \\
\hline
\end{tabular}




\begin{tabular}{|c|c|}
\hline & $\begin{array}{l}\text { schedule is } \\
\text { always } \\
\text { notified to } \\
\text { customers }\end{array}$ \\
\hline 2 & $\begin{array}{l}\text { Always give } \\
\text { announcemen } \\
\text { ts to notify } \\
\text { customers for } \\
\text { electricity } \\
\text { outages and } \\
\text { life }\end{array}$ \\
\hline 3 & $\begin{array}{l}\text { Provide } \\
\text { appropriate } \\
\text { service } \\
\text { information } \\
\text { for blackout } \\
\text { schedules }\end{array}$ \\
\hline 4 & $\begin{array}{l}\text { Providing } \\
\text { information } \\
\text { services in } \\
\text { accordance } \\
\text { with the } \\
\text { promised time }\end{array}$ \\
\hline 5 & $\begin{array}{l}\text { Strive for a } \\
\text { blackout } \\
\text { schedule a } \\
\text { week before } \\
\text { the schedule }\end{array}$ \\
\hline
\end{tabular}

Tabel 2. Quality Service Questionnaire Empathy

\begin{tabular}{cccc}
\hline $\begin{array}{l}\text { Quality } \\
\text { Questionnaire Empathy }\end{array}$ & \multicolumn{1}{c}{ Service } & B & TB \\
\hline Emphaty & & \\
\hline 1 & $\begin{array}{l}\text { Provide } \\
\text { individual } \\
\text { attention to } \\
\text { customers for } \\
\text { disruptions }\end{array}$ \\
\hline 2 & $\begin{array}{l}\text { Ease of } \\
\text { communicating } \\
\text { with customers }\end{array}$ \\
\hline 3 & $\begin{array}{l}\text { Always } \\
\text { prioritize the } \\
\text { interests of the } \\
\text { customers }\end{array}$ \\
\hline 4 & $\begin{array}{l}\text { Always } \\
\text { understand } \\
\text { customer needs }\end{array}$ \\
\hline
\end{tabular}




\begin{tabular}{ll}
\hline in explaining \\
cable \\
interference \\
problems
\end{tabular}

Tabel 3. Quality Service Questionnaire Responsiveness Quality Service

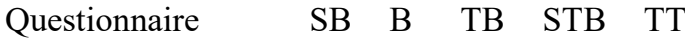

Responsiveness

Responsiveness

Patience

and

attention to

customers

1 in

providing

information

about

disruption,

blackouts

Response

speed

regarding

customer

complaints

about

2 service

during

outages,

cable

disruptions

and waiting

periods

Completion

of

complaints

3 faced by

customers

can be

resolved

quickly

Processing

speed of

customer

4 complaints

during the

waiting

period for 


\begin{tabular}{|c|c|c|c|c|c|}
\hline $\begin{array}{l}\text { Quality Service } \\
\text { Questionnaire } \\
\text { Responsiveness }\end{array}$ & SB & B & $\mathrm{TB}$ & STB & TT \\
\hline $\begin{array}{l}\text { power } \\
\text { failure and } \\
\text { interference }\end{array}$ & & & & & \\
\hline
\end{tabular}

Tabel 4. Quality Service Questionnaire Tangible

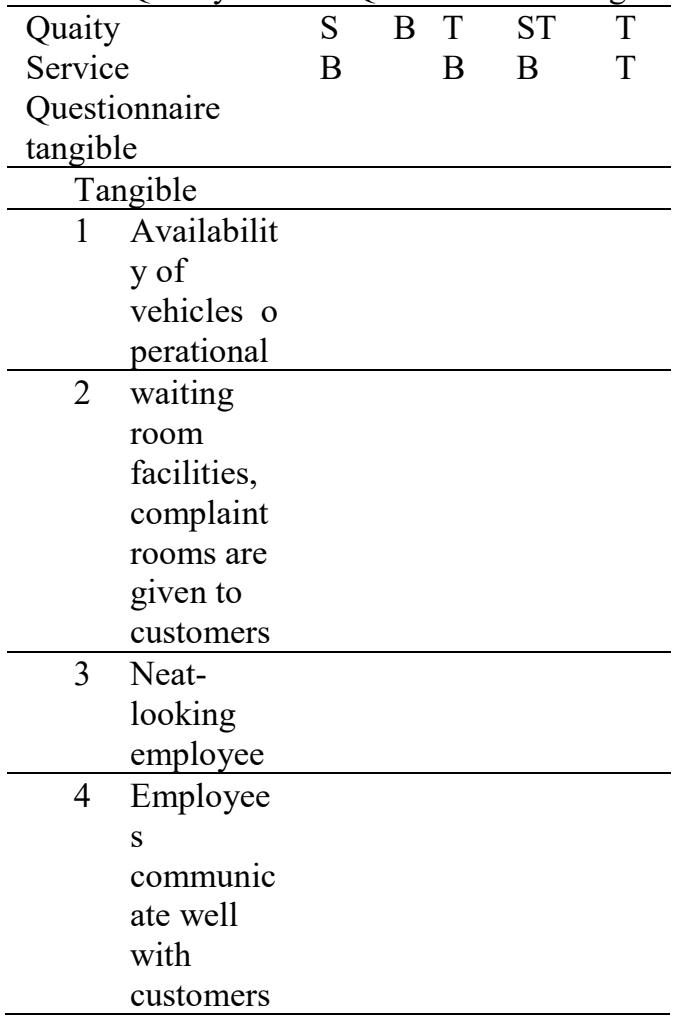

Tabel 5. Quality Service Questionnaire Assurance

\begin{tabular}{cccccc}
\hline $\begin{array}{l}\text { Quality Service } \\
\text { Questionnaire }\end{array}$ & SB & B & TB & STB & TT \\
\hline Assurance & & & & & \\
\hline & Guarantees & & & & \\
to & & & & & \\
1 & customers & & & & \\
& for repairs & & & & \\
and waiting & & & & \\
& periods & & & & \\
2 & $\begin{array}{l}\text { Customers } \\
\text { feel safe in }\end{array}$ & & & & \\
\hline
\end{tabular}




\begin{tabular}{|c|c|c|c|c|c|c|}
\hline \multicolumn{2}{|c|}{$\begin{array}{l}\text { Quality Service } \\
\text { Questionnaire }\end{array}$} & SB & B & TB & STB & $\mathrm{TT}$ \\
\hline & Assurance & & & & & \\
\hline & $\begin{array}{l}\text { reporting } \\
\text { disturbances }\end{array}$ & & & & & \\
\hline 3 & $\begin{array}{l}\text { Employees } \\
\text { are } \\
\text { consistently } \\
\text { polite } \\
\text { towards } \\
\text { customers } \\
\text { in providing } \\
\text { services }\end{array}$ & & & & & \\
\hline 4 & $\begin{array}{l}\text { Employees } \\
\text { have } \\
\text { sufficient } \\
\text { knowledge } \\
\text { to answer } \\
\text { customer } \\
\text { questions } \\
\text { with } \\
\text { problems } \\
\text { that are } \\
\text { often faced }\end{array}$ & & & & & \\
\hline
\end{tabular}

\section{Conclusions}

- With the forecasting information system using the least square method forecasting model can predict the service quality of each region which is seen from tangibles, reliability, responsiveness, assurance of each sector.

- Forecasting implementation can facilitate the PLN in analyzing the quality of service to the community in each region and knowing the highest priority so that in the future it can improve the performance of all PLN employees in Lhokseumawe City.

\section{References}

[1] Armstrong, A. and Kotler, K. (1999) Prinsip- Prinsip Pemasaran. Jakarta: Erlangga.

[2] Ginting, R. (2007) Sistem Produksi. Yogyakarta: Graha Ilmu.

[3] Heizer, J. and Render, B. (2009) Operations Management (Manajemen Operasi). Jakarta: Salemba Empat.

[4] Heizer, J. and Render, B. (2015) Manajemen Operasi. Edisi Ketu. Jakarta: Salemba Empat.

[5] Kotler, P. (2010) Manajemen Pemasaran, Edisi 13 Jilid 1 \& 2. Edisi Terjemahan. Edited by B. Sabran. Jakarta: Erlangga.

[6] Kotler, P. and Kevin, K. (2009) 'Manajemen Pemasaran. Edisi Kedua Belas, PT Indeks, Jakarta'. Jakarta: Erlangga.

[7] Parasuraman, A. V. (2001) Delivering Quality Service. New York: The Free Press.

[8] Pardede, P. (2005) Manajemen Operasi dan Produksi. Yogyakarta: Kanisius. 
[9] Prasetya, H. and Lukiastuti, F. (2009) Manajemen Operasi. Yogyakarta: Media Presindo.

[10] Stemvelt, R. C. (2004) Perception of Service Quality. Edited by Purwoko. Massachusetts: Allyn and Bacon.

[11] Subagyo, P. (1999) Forecasting (Konsep dan Aplikasi). Yogyakarta: BPFE.

[12] Supranoto, J. (2000) Statistika : Teori dan Aplikasi Jilid 1. Jakarta: Erlangga. 